\title{
ABNORMAL RETURN AND TRADING VOLUME ACTIVITY BEFORE AND AFTER PRESIDENTIAL ELECTION 2019 (Study on LQ-45 stock on February-July 2019)
}

\author{
C H Asta Nugraha \\ Business and Economic Faculty UNTAG Semarang \\ Email: chastanugraha@gmail.com \\ Suroto \\ Business and Economic Faculty UNTAG Semarang \\ Email: srt.smpg@yahoo.co.id
}

Received: July 2019; Accepted: July 2019; Available online: July 2019

\begin{abstract}
This study aims to find out the empirical evidence of Indonesia capital market investors' reaction toward presidential election 2019. The population in this study is the companies' stocks which are included in the LQ-45 index during this study. The data used is secondary data in the form of LQ-45 stocks and daily Composite index three days before and three days after the event. By implementing the one sample t-test and paired samples t-test, the result shows that there is a positive and significant abnormal return around the event especially on the third day $(t+3)$ after the event. Moreover, there is an insignificant difference in the average of negative abnormal return and significant difference on the average of negative trading volume activity, before and after the presidential election 2019.
\end{abstract}

Keywords: Capital Market, Event Study, Abnormal Return, Trading Volume Activity, Investors' Reactions

\begin{abstract}
Abstrak
Penelitian ini bertujuan untuk menemukan bukti empiris reaksi investor pasar modal Indonesia terhadap peristiwa pemilihan presiden 2019. Populasi penelitian ini adalah saham-saham perusahaan yang konsisten tergabung dalam indeks LQ-45 selama periode penelitian. Data yang digunakan adalah data sekunder berupa harga saham LQ-45 dan IHSG harian tiga hari sebelum dan tiga hari setelah peristiwa. Uji statistik yang digunakan untuk menguji hipotesis adalah one sample t-test dan paired samples t-test. Hasil yang diperoleh menunjukkan terdapat abnormal return positif dan signifikan di sekitar peristiwa terutama pada hari ke-3 $(t+3)$ setelah peristiwa. Selain itu, terdapat perbedaan rata-rata abnormal retrun negatif tidak signifikan dan terdapat perbedaan rata-rata trading volume activity negatif yang signifikan antara sebelum dan setelah peristiwa pemilihan presiden 2019.
\end{abstract}

Kata Kunci: Pasar Modal, Studi Peristiwa, Abnormal Return, Trading Volume Activity, Reaksi Investor

How to Cite: Nugraha, C. H. A., \& Suroto. (2019). Abnormal Return and Trading Volume Activity Before and After Presidential Election 2019 (Study on LQ-45 stock on February-July 2019). Media Ekonomi dan Manajemen, 34(2), 229-24. 


\section{INTRODUCTION}

Capital market is a market for sharing the financial instrument or valuable long term letters which can be sold and bought, in the form of debt or own stocks (Sutedi, 2011). As one of economical instrument, capital market cannot be separated from environment influence especially economic and politic environment. The more important role of capital market in economical event, the more sensitive that capital market toward many kinds of event around, whether it is directly related with economical issue or not (Suryawijaya and Setiawan, 1998).

Political event is one of the parts from non-economical environment that can affect on the capital market condition. This is because the dynamic of political situation that is related to economic matters stability of a country. Political stability, which is followed by stability economic condition, will make the investors feel safe to invest their fund in the capital market (Wardhani and Djazuli, 2012). The investors' expectation which caused by political event generally will appear on price fluctuate or trading volume activity (Sudewa and Sari, 2015). It is explained that political event like presidential and vice presidential election tend to get positive response or negative response from investors to do the transaction in capital market.

Presidential election is a political situation, which happens once in five years. Presidential election in 2019 is the battle between Joko Widodo as incumbent who has experience in leading government and Prabowo Subianto as the opponent who has no experience power so that both of them changed their political strategy become more accommodative. It makes people become more enthusiastic in using their vote to choose their choice, because president is the one who determines the political direction and economic policy in a country.

Some previous research about the investors' response in presidential election
2014 which is done by Diniar and Kiryanto (2015) approved that the test toward the difference of abnormal return and trading volume activity before and after the event showed significant result. On the other hand, Sudewa and Sari (2015), Suroto and Nugraha (2018), and then Wibowo and Darmanto (2019) concluded that the test toward the difference of abnormal return before and after the event showed that the result was not significant. Furthermore, Luhur (2010) states that there is no significant difference in trading volume activity between before and after the 2009 presidential election.

Based on the research gap above, the problem of this research such as (1) whether there is significant positive abnormal return in around the date of presidential election $17^{\text {th }}$ of April in 2019, and (2) whether there is difference of abnormal return and trading volume activity before and after presidential election on April 17 $7^{\text {th }} 2019$ ".

\section{LITERATURE REVIEW}

Efficient market is one of the situations where all the cost information can be gained openly and fast without any special obstacles (Hartono, 2016). According to Fama (1970) as cited by Fahmi (2012) stated that securities market is efficient if securities price showed full information provided. The efficiency of this capital market is not efficiency in financial administration but efficiency in the form of all information. It means that the securities price in capital market reflects the relevant information which affect the securities price (Martono and Harjito, 2011).

Event study is study about the market reaction toward an event which the information published as an announcement (Hartono, 2016). The marker reaction showed by the changing price of securities involved. This reaction can be measured by using abnormal return; an event which contain information will give abnormal return to the investors (Hartono, 2016). Beside using abnormal return, capital 
market reaction can be also seen by trading volume activity in the market where the information contain informative value if the amount of the stocks traded bigger or smaller when the event happend, compared with other time (Husnan, 1996).

Abnormal return is the over return which really happen toward normal return expected by the investors (Hartono, 2016), while the trading volume activity is an instrument which can be used to see the capital market reaction toward information through the movement parameter of stocks trading volume activity in the market (Sutrisno, 2010).

Signaling theory is a theory that sees the signs about the condition that describe a company (Fahmi and Hadi, 2009). Hartono (2016) explained that the event which contain information will give positive sign or negative sign to the investors in making investment decision. In this study, the signal means the information that can be gained by the investors from presidential election and that signal refers to the company which involved in LQ-45 index.

The capital market can react positive or negative toward political event. The positive reaction of capital market toward the event can be proven by Diniar and Kiryanto (2015) who examined the capital market reaction toward presidential election in 2014 and it was proven that the test of the difference of abnormal return and trading volume activity before and after the event showed that the result was significant.

The research result of Suryawijaya and Setiawan (1998), Mediawati and Harimawan (2004), Harjanto (2008), Alkaff (2010), Sudewa and Sari (2015), Mekel and Sihotang (2015) stated that there was no significant difference on the average of abnormal return before and after political event. From some of those researches can be stated that Indonesia capital market is getting more sensitive toward non-economic event and it can react toward political event. This is shown by the significant difference on abnormal return and the stocks of trading volume activity around the date of the event. The hypotheses in this study are

$\mathrm{H}_{1}$ : There was positive abnormal return and significant around the date of the presidential election 2019 happened.

$\mathrm{H}_{2}$ : There was difference on the average of abnormal return stocks before and after the presidential election in 2019.

$\mathrm{H}_{3}$ : There was difference on the average of trading volume activity stocks before and after presidential election in 2019.

\section{RESEARCH METHODS}

The population in this study is all companies which the stocks consistently listed in LQ-45 index members and they are always active in the trading every day and they do not do corporate action during the research period. There were 45 companies and the object of this study. The reason of choosing the LQ-45 stocks as the research population is based on the consideration that the stocks which are the most active traded in BEI. Therefore, it was expected the investors' reaction toward the presidential election can be seen through the stocks price movement and trading volume activity which is included in that LQ-45 index.

This study used event period during 6 days of stocks trading, three days before and three days after the event happens because when it was presidential election the stocks exchange was closed. This period used in order to know when the investors will start to give respond to the presidential election information and so that there was no other event appeared during the observation. Therefore, the research period is April $12^{\text {th }}$ until April $22^{\text {nd }} 2019$ because on weekdays the stocks exchange is closed.

The data used in this study is secondary data which is collected from www.IDX.co.id, www.finance.yahoo.com 
and social media. The data will be presented below:

1. The date of the presidential election was gained from social media.

2. The stocks which included in LQ-45 during the research period gained from www.IDX.co.id.

3. The price of the closing stocks which included in LQ-45 index and the price of the closing composite index on 6 days before until 5 days after the event gained from www.finance.yahoo.com.

The research subject in this study is investors' reaction which is measured using abnormal return and trading volume activity.

\section{Abnormal Return}

Abnormal return is the difference between the level of real return which happend with the return that the investors expect (Hartono, 2016). Mathematically, abnormal return formulated as bellow

$$
A R_{i, t}=R_{i, t}-E\left(R_{i}\right)
$$

Where:

$$
\text { ARi,t : abnormal return stocks i on }
$$
the day $t$

$$
A R_{i, t}=R_{i, t}-E\left(R_{i}\right)
$$

Ri,t : actual return stocks $i$ on the day $\mathrm{t}$

$\mathrm{E}(\mathrm{Ri})$ : expected return stocks $\mathrm{i}$.

Actual return stocks $i$ on the day $t\left(R_{i, t}\right)$, can be calculated using this formula

$$
R_{i, t}=\frac{P_{i, t}-P_{i, t-1}}{P_{i, t-1}}
$$

Where:

$\mathrm{P}_{\mathrm{i}, \mathrm{t}} \quad$ : stocks price $\mathrm{i}$ on the day $\mathrm{t}$

$\mathrm{P}_{\mathrm{i}, \mathrm{t}-1}$ : stocks price $\mathrm{i}$ on the day $\mathrm{t}-1$

Expected return stocks i $\left[\mathrm{E}\left(\mathrm{R}_{\mathrm{i}}\right)\right]$

calculated using Market-adjusted model

$$
\mathrm{R}_{\mathrm{m}, \mathrm{t}}=\frac{\mathrm{IHSG}_{\mathrm{t}}-\mathrm{IHSG}_{, \mathrm{t}-1}}{\mathrm{IHSG}_{\mathrm{i}, \mathrm{t}-1}}
$$

$\mathrm{R}_{\mathrm{m}, \mathrm{t}} \quad$ : return market on the day $\mathrm{t}$
$\mathrm{IHSG}_{\mathrm{t}}$ : composite index on the day $\mathrm{t}$ $\mathrm{IHSG}_{\mathrm{t}-1}$ : composite index on the day $\mathrm{t}-1$ Trading Volume Activity (TVA)

Trading Volume Activity shows the activity of stocks trading and reflects how active the stocks traded in capital market. The trading volume activity can be formulated as below (Jones, 1986).

$$
\mathrm{TVA}_{\mathrm{i}, \mathrm{t}}=\frac{\sum \text { Stock } \mathrm{i} \text { traded at day } \mathrm{t}}{\sum \text { Stock i circulated at day } \mathrm{t}}
$$

The analytical tool used in this study is descriptive analysis which is an analysis by showing the minimum, maximum, average values and standard deviations from the counting result and inferential analysis included normality data test and hypothesis test. The normality data test using Kolmogorov Smirnov test and the first hypothesis test using One sample t-test while the second and the third hypothesis test using Paired samples t-test if the data distribution normal. If the data distribution is not normal, the test used Wilcoxon test.

\section{RESULT AND DISCUSSION The description of Abnormal Return}

The descriptive statistic counting result of the average abnormal return of the stocks during 6 days of this study period presented in the Table 1.

The Table 1 showed that average abnormal return before and after the event has maximum value each is 0,0281 and 0,0282 , while the minimum value each is $-0,0259$ and $-0,0235$. That value showed that the average abnormal return component is varied. For the average abnormal return before and after the event each is 0,0017 and 0,0031 and it has positive sign. It shows that the investors' reaction of Indonesia capital market is positive toward the presidential election 2019. The deviation between actual return value and expected return, which has farther deviation, happen on the average abnormal return before the event than the average abnormal return after the event. This deviation can be seen in the deviation 
standard value where each of them is 0,0126 and 0,0111 . It is presented in the form of a figure to show the condition of average abnormal return altogether during the observation period.

Figure 1 above showed that the highest value of average abnormal return during the observation period on $t+3$ is 0,010 . The positive average abnormal return showed that the investors in Indonesia stocks exchange have a chance to get big profit if do the transaction on the third day after the event compare to the previous days. It is because the actual return is bigger than the expected return. The lowest average abnormal return during the research period happen on $t+1$ is $-0,002$. The negative average abnormal return showed that invest on $\mathrm{t}+1$ does not give big profit compare to other period. It is because the actual return is smaller than the expected return on the other period.

Table 1. Descriptive Statistic Abnormal Return during the event period

\begin{tabular}{lccccc}
\hline Period & $\mathrm{N}$ & Minimum & Maximum & Mean & $\begin{array}{c}\text { Standard } \\
\text { Deviation }\end{array}$ \\
\hline Three days before & 45 & $-0,0259$ & 0,0281 & 0,0017 & 0,0126 \\
Three days after & 45 & $-0,0235$ & 0,0282 & 0,0031 & 0,0111 \\
\hline
\end{tabular}

The sources: Secondary data which has been processed in 2019

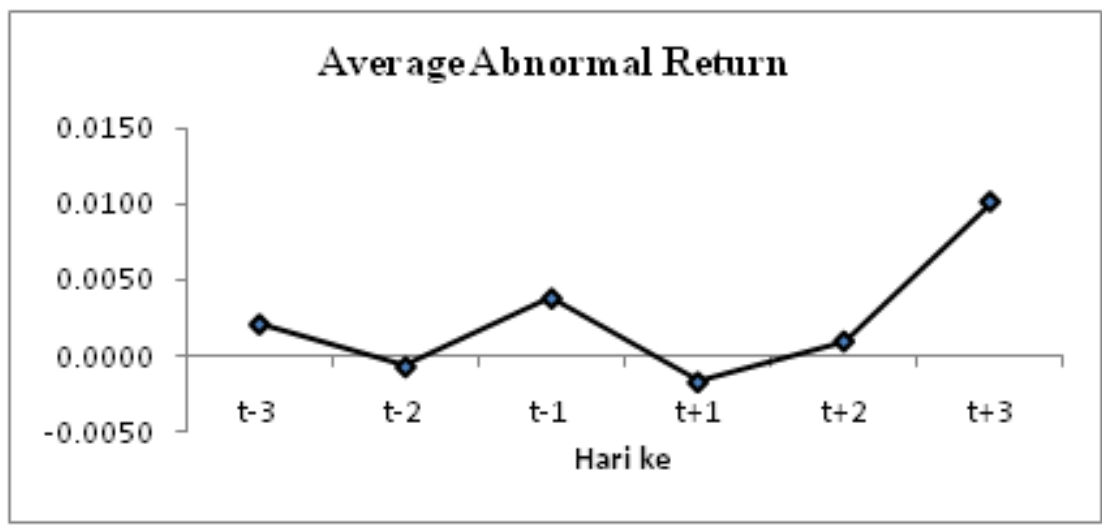

The source : Secondary Data which has been processed 2019

Figure 1. Average Abnormal Return Stocks Chart

\section{The description of Trading Volume Activity}

The descriptive statistic counting result of the average abnormal return of the stocks during 6 days of this study period presented in the Table 2. The Table 2 showed that the average trading volume activity before and after the event have maximum value each of them is 0,0098 and 0,0144 , while the minimum value is 0,0002 . That value showed that the component of average trading volume activity is varied.

For the average trading volume activity before and after the event each of them is 0,0019 and 0,0026 and they have positive sign. It indicates that there was reaction from Indonesia capital market investors toward presidential election 2019. Therefore, the average trading volume is getting increased 0,0007.

The deviation between actual trading volume activity and expected trading volume activity which has farther deviation happen on average trading volume activity before the event than the average trading volume activity after the event. This deviation can be seen in the deviation standard value where each of them is 0,0023 and 0,0033 .

It is presented in the form of a figure to show the condition of average abnormal 
return altogether during the observation period.

The Figure 2 showed that the highest value of average trading volume activity during the research period happen on $t+1$ 0,0036. The average trading volume activity, which has high value, showed that the first day after the event becomes the most hectic from the 6 days of research period. It is because the trading volume is bigger than the other five days. The lowest average trading volume activity happen on $\mathrm{t}-3$ 0,0015. That value showed that on the third day before the event the stocks of volume traded is lower than the other five days.

Table 2. Descriptive Statistic Abnormal Return during the event period

\begin{tabular}{lccccc}
\hline Period & $\mathrm{N}$ & Minimum & Maximum & Mean & $\begin{array}{c}\text { Standard } \\
\text { Deviation }\end{array}$ \\
\hline 3 days before & 45 & 0,0002 & 0,0098 & 0,0019 & 0,0023 \\
3 days after & 45 & 0,0002 & 0,0144 & 0,0026 & 0,0033 \\
\hline
\end{tabular}

The source: Secondary Data which has been processed 2019

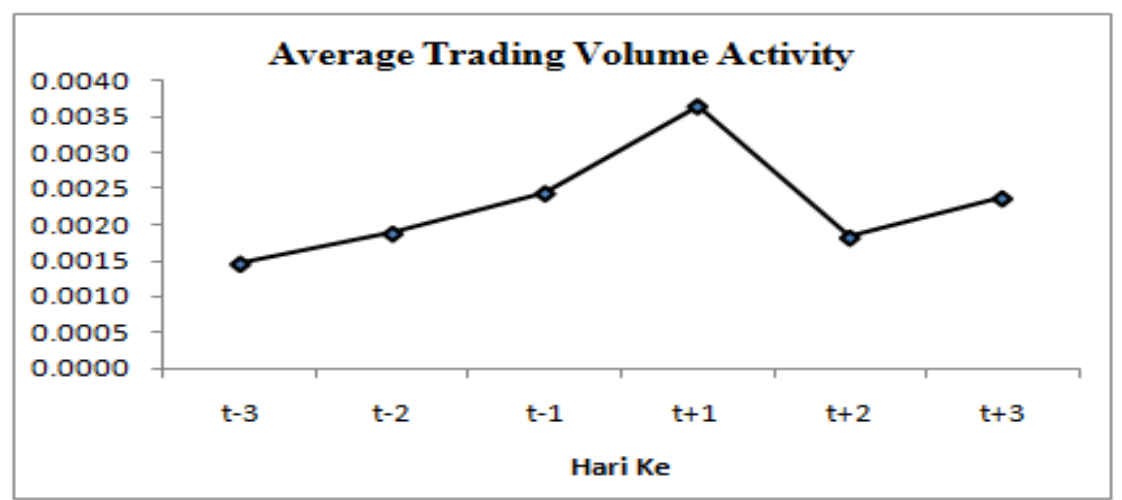

The source: Secondary Data which has been processed 2019

Figure 2. Average Abnormal Return Stocks Chart

\section{Normality Test}

The normality test done in order to determine the statistical parametric test or non parametric. The result of data normality test can be seen on the Table 3 . It can be known that the abnormal return data during the event period, average abnormal before and after the event was distributed normally while the average trading volume activity data before and after the event was not distributed normally. The data which was not distributed normally can be transformed as normal data. It must be known the histogram chart to determine the transformation type (Ghozali, 2016).
Figure 3 and Figure 4 are the histogram chart ATV data before and after the event. Those two charts showed that the data was not distributed normally and skewed to the left (positive skewness), so the data must be changed into natural logarithm. After the transformation then conducted the normality test again with the result as follow Tabel 4. It showed that ATVA data which was not distributed at the beginning after the transformation it was changed into distributed normally. It means that the first hypothesis used one sample t-test, while the second and the third hypothesis used paired samples t-test. 
Table 3. The result of data normality test

\begin{tabular}{lllccl}
\hline Period & Variable & $\mathrm{N}$ & $\begin{array}{c}\text { Value } \\
\mathrm{Z}\end{array}$ & $\begin{array}{c}\text { Asymp.Sig. } \\
(2-\text { tailed })\end{array}$ & Conclusion \\
\hline $\mathrm{T} \_3$ & AR & 45 & 0,915 & $0,372>\alpha=0,05$ & Normal \\
$\mathrm{T} \_2$ & AR & 45 & 1,212 & $0,106>\alpha=0,05$ & Normal \\
$\mathrm{T} \_1$ & AR & 45 & 0,552 & $0,921>\alpha=0,05$ & Normal \\
$\mathrm{T}+1$ & AR & 45 & 0,516 & $0,953>\alpha=0,05$ & Normal \\
$\mathrm{T}+2$ & AR & 45 & 0,791 & $0,559>\alpha=0,05$ & Normal \\
$\mathrm{T}+3$ & AR & 45 & 0,859 & $0,451>\alpha=0,05$ & Normal \\
Before & AAR & 45 & 0,703 & $0,707>\alpha=0,05$ & Normal \\
After & AAR & 45 & 0,659 & $0,778>\alpha=0,05$ & Normal \\
Before & ATVA & 45 & 2,036 & $0,001<\alpha=0,05$ & Not Normal \\
After & ATVA & 45 & 2,140 & $0,000<\alpha=0,05$ & Not Normal \\
\hline
\end{tabular}

Resource : Secondary data processed, 2019.

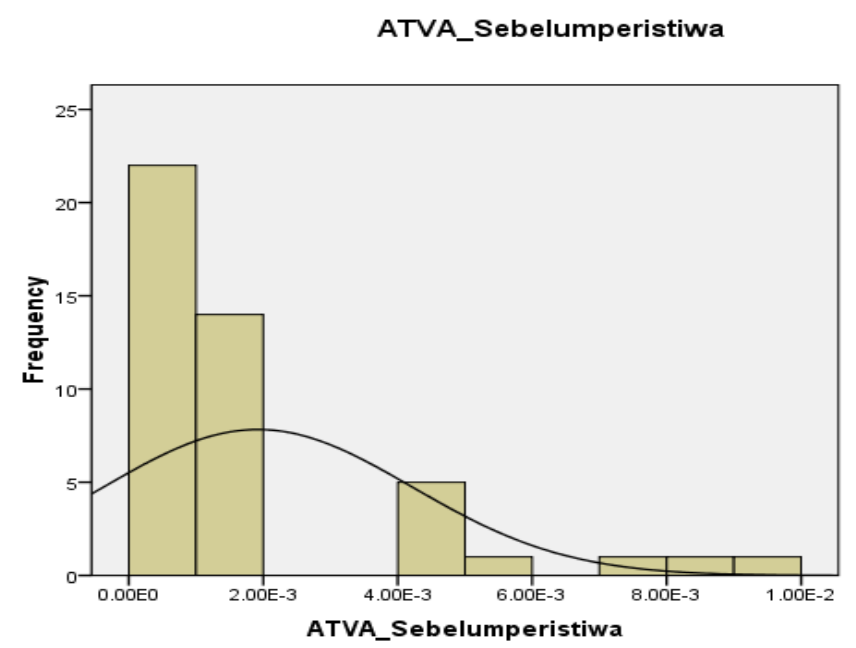

$\begin{aligned} & \text { Mean }=0.00 \\ & \text { Std. Dev. }=0.002 \\ & N\end{aligned}$

Resource : Secondary data processed, 2019.

Figure 3. Histogram Chart before the event

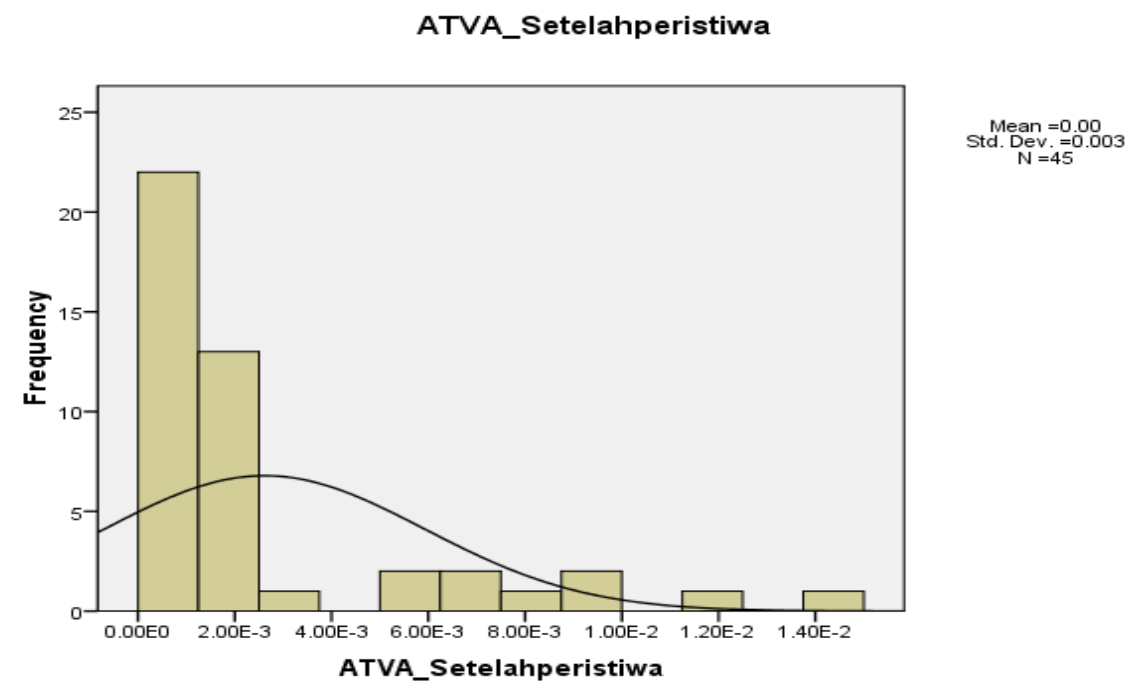

Resource: Secondary data processed, 2019.

Figure 4. Histogram Chart after the event 
Table 4. The result of Data Normality Test

\begin{tabular}{lllccl}
\hline Period & Variabel & N & $\begin{array}{c}\text { Value } \\
\text { Z }\end{array}$ & Asymp.Sig. (2- tailed) & Conclusion \\
\hline Before & LN_ATVA & 45 & 0,671 & $0,977>\alpha=0,05$ & Normal \\
After & LN_ATVA & 45 & 0,759 & $0,295>\alpha=0,05$ & Normal \\
\hline
\end{tabular}

Resource: Secondary data processed, 2019.

\section{Hypothesis Test \\ First Hypothesis}

The result of the first hypothesis test which showed that there was positive abnormal return and significant around the date of presidential election 2019 can be seen in the Table 5. It can be known that during 6 days of the event period there was positive average abnormal return and negative but not significant on the third day before the event until the second day after the event. However, there was positive average abnormal return and significant on the third period after the event with the significant value 0,001 smaller than $\alpha=0,05$. It can be concluded that the first hypothesis which found there was positive abnormal return and significant around the event period accepted. Except analysis the market reaction toward the presidential election based on average abnormal return (AAR), the analysis is also about the market reaction based on cumulative abnormal return (CAR). The analysis using CAR aims to see the preference of the market react around the event period.

The result of the first hypothesis test using CAR can be seen in Table 6. It can be known that the market react positively and significant on the third day before the event until the third day after the presidential election 2019. The CAR value on that day is 0,0024 with the significant value smaller than $\alpha=0,05$. This result strengthen the first hypothesis which explained that there was positive abnormal return and significant around the event period. From the six table can be concluded that presidential election 2019 was as political event that contain information responded as good news by Indonesia capital market investors.

Table 5. The result of One sample t-test around the event period

\begin{tabular}{lccl}
\hline Period & $\begin{array}{c}\text { Average Abnormal } \\
\text { Return }\end{array}$ & Asymp.Sig. (2- tailed) & Conclusion \\
\hline $\mathrm{t}-3$ & 0,0022 & $0,547>\alpha=0,05$ & Not significant \\
$\mathrm{t}-2$ & $-0,0008$ & $0,796>\alpha=0,05$ & Not significant \\
$\mathrm{t}-1$ & 0,0038 & $0,182>\alpha=0,05$ & Not significant \\
$\mathrm{t}+1$ & $-0,0016$ & $0,619>\alpha=0,05$ & Not significant \\
$\mathrm{t}+2$ & 0,0010 & $0,757>\alpha=0,05$ & Not significant \\
$\mathrm{t}+3$ & 0,0100 & $0,001<\alpha=0,05$ & Significant \\
\hline
\end{tabular}

Resource: Secondary data processed, 2019.

Table 6. The result of One sample t-test around the event period

\begin{tabular}{cccl}
\hline Period & $\begin{array}{c}\text { Cumulative Average } \\
\text { Abnormal Return }\end{array}$ & $\begin{array}{c}\text { Asymp. Sig. } \\
\text { (2-tailed) }\end{array}$ & \multicolumn{1}{c}{ Conclusion } \\
\hline $\mathrm{t}-1{ }_{-} \mathrm{t}+1$ & 0,0021 & $0,668>\alpha=0,05$ & Not significant \\
$\mathrm{t}-2{ }_{-} \mathrm{t}+2$ & 0,0023 & $0,734>\alpha=0,05$ & Not significant \\
$\mathrm{t}-3 \_\mathrm{t}+3$ & 0,0024 & $0,048<\alpha=0,05$ & Significant \\
\hline
\end{tabular}

Resource: Secondary data processed, 2019. 


\section{Second Hypothesis}

The second hypothesis test found that there was difference of average abnormal return of the stocks before and after presidential election 2019. The test done using paired samples t-test and it was gained this result as Table 7 . The result showed that the difference of the average abnormal return is 0,0014 and it has significant value 0,061 . It is because 0,061 is bigger than $\alpha=0,05$, so the inference taken is accepting null hypothesis which there was no difference of the average abnormal return stocks before and after presidential election 2019 with 95\% trusted.

Table 7. The result of paired samples t-test toward the difference of abnormal return

\begin{tabular}{cccc}
\hline Period & $\begin{array}{c}\text { Difference between } \\
\text { Abnormal Return }\end{array}$ & $\begin{array}{c}\text { Asymp. Sig. } \\
\text { (2-tailed) }\end{array}$ & Conclusion \\
\hline Pair-1 Before - After & 0,0014 & $0,601>\alpha=0,05$ & Not significant \\
\hline \multicolumn{4}{r}{ Resource: Secondary data processed, 2019. }
\end{tabular}

\section{Third Hypothesis}

The result of the third hypothesis test showed that there was difference on the average trading volume activity stocks before and after the presidential election 2019. The test done using paired samples t-test and the result as Table 8 . The result of paired sample t-test showed that the difference of average trading volume activity is 0,0007 and it has significant value 0,009 smaller than $\alpha=0,05$, so the inference taken is accepting alternative hypothesis that found the difference of average trading volume activity stocks before and after presidential election 2019 with $95 \%$ trusted.

Table 8. The result of paired samples t-test toward the difference of trading volume activity

\begin{tabular}{cccc}
\hline Period & $\begin{array}{c}\text { Difference Average Trading } \\
\text { Volume Activity }\end{array}$ & $\begin{array}{c}\text { Asymp. Sig. } \\
(2 \text {-tailed })\end{array}$ & Conclusion \\
\hline Pair-1 Before - After & 0,0007 & $0,009<\alpha=0,05$ & significant \\
\hline \multicolumn{4}{c}{ Resource : Secondary data processed, 2019. }
\end{tabular}

\section{Discussion}

\section{There was Abnormal Return Around The Event}

The result of the first hypothesis $\left(\mathrm{H}_{1}\right)$ showed that presidential election 2019 gave positive signal of the information toward stocks exchange activity or the increased stock price movement. It can be seen from the changing of average abnormal return which tend to increase before and after presidential election 2019.

The investors' reaction is positive and significant on the third day after presidential election 2019. It was proven by the increasing of composite index on April $22^{\text {nd }} 2019$ until $6.462,82$ which is the highest during the event period. Investors will do the purchasing stocks when the stocks exchange open after Sunday. It was expected that foreign investors would join the stocks exchange so dollar will strengthen rupiah. From those considerations the stocks price will be increased higher so it will increase the composite index.

The result of this study is the same as Setyawan (2006) said that the information that contains good news will cause the stock price increased but if the information contain bad news will cause the stock price decreased. The result of this study is the same as the statement of Martono and Harjito (2011). They said that the securities price in the capital market reflected the relevant information and affect to that securities cost.

Beside that the result is also the same as Budiarto and Baridwan (2009) 
statement. They said that market reaction as the signal of information a certain event can affect the company value that reflect from the changing price and trading volume activity.

\section{There was Difference Average Abnormal Return Before and After The Event}

The statistical test on the average abnormal return during the event period found that there was no significant difference between average abnormal return before and after presidential election 2019. It is related to the company stocks that consistently incorporated in LQ-45 index. That result indicates that the investors have anticipated the event by making safety net where the investors do not do the transaction much. However, one day after presidential election 2019 found that there was decreasing of average abnormal return. It means there was bad news. The presidential election 2019 run safe but the investors responded not in a good way. It is because there was no certain winner of the election. Based on quick count, the first candidate declared as the winner but the second candidate also declared their winning.

This research result supported the research of Siregar and Sianturi (2005) and Amirta concluded that there was no difference of average abnormal return before and after the presidential election.

\section{There was Difference of Average Trading Volume Activity Before and After The Event}

From the different test result of average trading volume activity before and after the presidential election 2019 showed that there was significant difference between the average trading volume activity before and after the event toward the company stocks that consistently incorporated in LQ-45 index. The average trading volume activity value showed that there was increasing on $t+1$ compare to the average trading volume activity before the presidential election 2019. It is because the selling stocks stars when Indonesia stock exchange opens after the event. The investors feel worried and tend to sell their stocks in order to save their asset.

The presidential election 2019 also cause the trading volume activity increased on the first day after. The quick count affects the increasing of trading volume activity before and after the event. The different resources of quick count which using exit pull version from second candidate make the investors confused. It indicates that even trading volume activity increased and usually the investors want to buy or sell the stocks but it does not mean that they will get the profit as what they expect. In this study found that even the result of trading volume activity significant but not the same as abnormal return that is significant.

This study is the same as Sundari (2009) study that is also about the presidential election on April $9^{\text {th }} 2009$ showed the same result that abnormal return was not significant toward LQ-45 stocks. Anwar (2004) in presidential election on April $5^{\text {th }} 2004$ in Jakarta stocks exchange showed that there was significant trading volume activity result toward LQ-45 stocks. Ananto (2014) in presidential election on April $9^{\text {th }} 2014$ showed that abnormal return was not significant and significant trading volume activity toward stocks in JII.

From the three hypothesis in this research, only one hypothesis which is the second hypothesis refused. The reason why the second hypothesis refused was the hypothesis built in this study was presidential election that gave positive signal to the investors in capital market based on the result survey conducted by some survey organization. From some survey result showed that the president as incumbent will win the election. The victory of the president as incumbent will be accepted in the market because the president has shown his best work during his governement. 
It is assumed that the capital market will have good performance and give higher abnormal return after the presidential election.

The fact of the statistic test showed that there is no significant difference between the average of abnormal return after and before the presidential election. This situation probably caused by the day after the election, eventhough quick count showed that the president as incumbent won but the opponent also did quick count based on their version. Moreover, they declared their victory. It makes the investors confused and they gave negative response by selling their stocks in order to get profit even it is not as big as their expectation. At the last day, one day after presidential election the average of abnormal return showed negative (see 1st figure). On the second day the average of abnormal return is getting higher until the third day.

Beside that, the result of this study supported the main theory used in study. The theory is market efficiency and signaling theory. It means that every announcement published which contain information based on investors perception will be responded posively or negatively.

\section{CONCLUSION AND RECOMMEN- DATION}

The conclusion of these study are firstly there was positive abnormal return and significant around the presidential election 2019. It was shown using cumulative abnormal return test that contain information so that the market react. Second, there was no difference in average abnormal return before and after the event. It is because the capital markets investors' actions tend to prepare the speculation which assumed give profit to the investors on the days around the presidential election 2019. Third, there was difference in average trading volume activity before and after the presidential election 2019. It is because the stock selling action did by investors when the stocks exchange open after the event. The investors feel panic because there was no certain national politic thing and they tend to sell their stocks to save their assets.

These are some suggestions for the next research can be added the other variable except abnormal return and trading volume activity. The population or sample of this research is better using the company in the other sector in order to see the influence of the presidential election in different side. For the next research suggested using mean adjusted or market model in counting return market so that the result can be compared.

\section{REFERENCES}

Alkaff, M.Q. (2010). Pengaruh Pemilihan Presiden RI Tahun 2009 Terhadap Harga Saham Dan Volume Perdagangan Saham Perusahaan di Bursa Efek Indonesia (Event Study Pada Saham Anggota JII). Skripsi, Jurusan Akuntansi Fakultas Ekonomi Universitas Pembangunan Nasional "Veteran" Jawa Timur.

Ananto, D. (2014). Pengaruh Pemilu Legislatif Terhadap Abnormal Return dan Trading Volume Activity Saham Di Jakarta Islamic Index (Studi Kasus Pada Peristiwa Pemilu Legislatif 09 April 2014). Skripsi. Universitas Islam Negeri Kalijaga Yogyakarta.

Anwar, C. (2004). Studi Peristiwa Reaksi Pasar Terhadap Pemilihan Umum Tanggal 5 April 2004 Pada Bursa Efek Jakarta, Skripsi. Universitas Gunadarma. Jakarta .

Asmita, M. (2005). Reaksi Pasar Modal Indonesia Terhadap Pemilu 2004 aham LQ45 di Bursa Efek Indonesia), Tesis. Universitas Diponegoro, Semarang. 
Budiarto, A., \& Zaki, B. (2009). Pengaruh Pengumuman Right Issue terhadap tingkat keuntungan dan likuiditas saham periode 1994-1996. Jurnal Riset Akuntansi Indonesia, 2(1),

Dinar, A. H., \& Kiryanto. (2015). Analisis Dampak Pemilu Presiden Jokowi Terhadap Return Saham (Studi Kasus Saham LQ-45 di Bursa Efek Indonesia). Jurnal Akuntansi Indonesia, 4(2), 97-108.

Fahmi, I. (2012). Manajemen Investasi (Teori dan Soal Jawaban). Jakarta: Salemba Empat.

Fahmi, I., \& Hadi, Y. (2009). Teori Portofolio dan Analisis Investasi. Alfabeta, Bandung.

Ghozali, I. (2006). Aplikasi Analisis Multivariate dengan Program SPSS. Semarang: Badan Penerbit Universitas Diponegoro.

Harjanto, H. D. (2008). Reaksi Pasar Modal Indonesia Sehubungan Politik Dalam Negeri (Event Study Pada Pengumuman Hasil Pilkada DKI Jakarta Tanggal 6 Agustus 2007). Skripsi. Jurusan Manajemen Fakultas Ekonomi Universitas Muhamdiyah Surakarta.

Hartono, J. (2016). Teori Portofolio dan Analisis Investasi. Edisi kesepuluh. Yogyakarta: BPFE. Universitas Gajah Mada.

Husnan, S. (1996). Dasar-dasar teori portofolio dan analisis sekuritas. Yogyakarta: UPP AMP YKPN

Luhur, S. (2010). Reaksi Pasar Modal Indonesia Seputar Pemilihan Umum 8 Juli 2009 Pada Saham LQ-45. Jurnal Keuangan dan Perbankan, 14(2), 249-262.

Jones, C. P. (1986). Investment: Analysis and Management, Sixth Editions. John Wiley and Sons Publisher, New Jersey
Martono \& Harjito, A. (2011). Manajemen Keuangan. Edisi Kedua, Cetakan Pertama, Yogyakarta: Ekonosia.

Meidawati, N., \& Harimawan, M. (2004). Pengaruh Pemilihan Legislatif Indonesia Tahun 2004 Terhadap Return Saham Dan Volume Perdagangan Saham LQ45 di PT. Bursa Efek Indonesia (BEI). Sinergi, 7(1), 89-101.

Setyawan, W. (2006). Pengaruh Peristiwa-peristiwa Politik Terhadap Pergerakan Saham Pada Bursa Efek Indonesia. Jurnal Ekonomi dan Bisnis, 1(3).

Sihotang, E. M., \& Mekel, P. A. (2015). Reaksi Pasar Modal Terhadap Pemilihan Umum Presiden Tanggal 9 Juli 2014 Di Indonesia (Studi di Perusahaan Konstruksi, Infrastruktur dan Utilitas Pada BEI, Jakarta). Jurnal EMBA, 3(1), 951-960.

Siregar, B \& Sianturi, T.S.S. (2005). Reaksi Pasar Modal Terhadap Pemilihan Umum dan Pergantian Pemerintahan Tahun 2004. Jurnal Akuntansi dan Manajemen, XVI.

Sudewa, D.G.O., \& Sari, M. M. R. (2015). Reaksi Pasar Atas Peristiwa Pilpres 2014. E-Jurnal Akuntansi Universitas Udayana, 12(3), 465-480.

Sundari, V. (2009). Reaksi Pasar Modal Indonesia Atas Pelaksanaan Pemilihan Umum 9 april 2009 Pada Bursa Efek Indonesia. Skripsi. Universitas Guna Darma. Jakarta.

Suroto \& Nugraha, A. (2018). Indonesian Capital Market Investor Response Toward The Simultaneous Regional Elections In 2018 (Study On Lq45 Stocks February Until July 2018), IOSR Journal of Economics and Finance (IOSR-JEF), 5, 9-15. 
Suryawijaya, M. A., \& Setiawan, F. A. (1998). Reaksi Pasar Modal Indonesia Terhadap Peristiwa Politik Dalam Negeri (Event Study pada Peristiwa 27 Juli 1996). Kelola, 7 (1998).

Sutedi, A. (2011). Pasar Modal Syariah Sarana Investasi Berdasarkan Prinsip Syariah (Pertama). Jakarta: Sinar Grafika.

Sutrisno, W. (2010). Manajemen Keuangan, Teori, Konsep dan Aplikasi, Yogyakarta: Ekonisia.

Wardhani, L. S. \& Djazuli, A. (2012). Reaksi Pasar Modal Indonesia Terhadap Peristiwa Pemilihan Gubernur DKI Jakarta Putaran II 2012 (Event Study pada Saham Anggota Indeks Kompas 100). Skripsi. Jurusan Manajemen Fakultas Ekonomi dan Bisnis Universitas Brawijaya Malang.

Wibowo, A., \& Darmanto, S. (2019). Impact of Quick Count Result of President Election on Stock Prices and Trade Activities in the Indonesian Capital Market. Saudi Journal of Business and Management Studies, 4(6), 487-493. 